\title{
Этноэкономика в действии: опыт Тувы и Алтая 1
}

С.А. МАДЮКОВА, кандидат философских наук, Институт философии и права CO PAH. E-mail: sveiv7@mail.ru;

О.А. ПЕРСИДСКАЯ, ИНстИтут фИлософии и права СО РАН, Новосибирск.

E-mail: olga_alekseevna@mail.ru

Рассмотрены потенциал этноэкономического уклада для развития моделей региональных экономик, а также конкретные формы и практики этноэкономического неотрадиционализма в жизнедеятельности этнических групп республик Тыва и Алтай. Конкретные этнокультурные традиции и традиционное хозяйствование тувинцев и алтайцев рассмотрены, с одной стороны, как ресурсы повышения экономической стабильности регионов. С другой стороны, анализ форм бытования неотрадиционализма позволил зафиксировать такие неотрадиционные тренды, как рационализация и коммерциализация традиционного, тенденции замещения аутентичной культуры эрзац-формами. Выявлены конкретные сферы и механизмы монетизации традиционного: этнотуризм и традиционное природопользование, этнокухня и этномода, горловое пение как бренд и низкая конкурентоспособность национальных языков.

Ключевые слова: этнос, этнокультура, этноэкономический уклад, эрзац, нео-

традиционализм

\section{Этноэкономический уклад и неотрадиционализм. Проблемная ситуация}

Регионы Российской Федерации неоднородны по показателям своей экономической успешности. Исследователи российских социально-экономических процессов нередко указывают на проблемы неравномерности социального и экономического развития регионов и разного уровня доступа их представителей к ресурсам. Сравнивая регионы Российской Федерации с позиций интенсивности хозяйственной активности, финансовой самодостаточности, привлекательности региона как места проживания и инновационной активности, Н.Н. Киселева и В.В. Браткова отмечают, что по совокупности данных показателей на общероссийском уровне невыигрышно смотрятся республики СевероКавказского федерального округа, а также республики Алтай,

\footnotetext{
${ }^{1}$ Работа выполнена в рамках раздела «Этнокультурные механизмы пространственного развития Сибири» междисциплинарного проекта «Экономико-географические, этнокультурные и историко-демографические механизмы пространственного развития Сибири» Комплексной программы фундаментальных научных исследований СО РАН II.1.
} 
Тыва, Бурятия, Мордовия, то есть так называемые «этнические» регионы, где значительны доли нетитульного населения. Авторы делают акцент на том, что в данных регионах практически «отсутствуют условия и стимулы самостоятельного территориального развития» [Киселева, Браткова, 2016. С. 131].

Одним из действенных механизмов преодоления локальных экономических кризисов считается формирование этноэкономического уклада с опорой на этноэкономический неотрадицุионализм. Экономический традициионализм как «совокупность издавна существующих хозяйственных форм и институтов, ныне уже устаревших и в большинстве стран не обеспечивающих реального, т.е. с учетом роста населения, экономического роста и в целом общественного прогресса» [Бессонов, 2004], по мнению С.А. Бессонова, до сих пор существует в большинстве развивающихся и переходных стран. Причем традиционные виды экономической деятельности в обществах таких стран, по мнению автора, часто настолько преобладают над современными, что ниша современной экономики является незначительной и сегментарной.

Нам представляется более адекватным современным условиям использование концепта неотрадиционализм. В концепции А.И. Пики неотрадиционализм предполагает стремление к нахождению и поддержанию равновесия между: 1) целями экономического развития северной региональной промышленности и традиционного хозяйства северных народов; 2) требованиями экологической рациональности и необходимости щадящего режима природопользования; 3) задачами сохранения и развития этнокультурной самобытности народов Севера [Пика, 1996. С. 51]. Основная идея А.И. Пики - акцент на традиционном хозяйстве, натуральной экономике, которые определяют, в конечном итоге, этничность.

Обратной стороной медали является зафиксированная Ч.К. Ламажаа проблема того, что «традиции стали в отдельных местах особой заботой социальной, культурной политики властей, в традиционных видах деятельности часть населения стала находить возможности не просто для самоидентификации, но и для предпринимательства. ... Определенная деятельность имеет столь узкую направленность, что исследователи характеризуют их даже терминами “псевдо”, “лже”, “квази» и пр.»” . А потому исследование как достоинств регионального этноэкономического уклада с опорой на неотрадиционализм, так и его слабых сторон, выражающихся в манипуляциях традиционным и его фальсификации как «этнически брендированного», является значимой социальной и научной проблемой.

\section{Этноэкономический уклад в жизнедеятельности регионального сообщества}

Признавая актуальной задачу сокращения разницы социально-экономических показателей регионов, отметим, что сами региональные различия могут быть рассмотрены как точки роста для поиска программ эффективных стратегий экономического развития. При этом определяющую роль в формировании отличительной специфики региона играют этнические группы, населяющие его. Особое значение этническая составляющая имеет для национальных регионов, экономический уклад которых слабовосприимчив к модернизации по западному типу. Социально-экономический прогресс этнических регионов возможен при условии реализации моделей региональной экономики, опирающихся на традиционные типы хозяйствования этнических групп, сформировавшиеся с опорой на традиции, обычаи, культуру, психологию, религиозные воззрения. Их называют этноэкономическими укладами. Такой уклад является наиболее адекватной хозяйственной стратегией для той географической, природной и социальной среды, в которой он исторически формировался. При этом этноэкономический уклад обладает высокой степенью жизнеспособности на индустриальных и даже постиндустриальных стадиях общественного развития за счет высокой степени адаптивности своих форм. Этноэкономическая деятельность обладает значительным потенциалом для развития сельских территорий, так как предполагает экстенсивный тип занятости с использованием преимущественно аграрного сырья и трудозатратный тип воспроизводства [Гонтарь, 2015. С. 59].

Стратегия внедрения элементов этноэкономического уклада в систему хозяйствования на уровне регионов Российской

${ }^{2}$ Научно-исследовательская база данных «Российские модели архаизации и неотрадиционализма»: Сибирский федеральный округ (2014) [Эл. pecypc]. URL: http://www. neoregion.ru/sfo.html (дата обращения: 28.02.2018). 
Федерации может способствовать решению нескольких задач. Прежде всего, это задача сокращения экономической дифференциации регионов, решаемая за счет стабилизирующей функции этноэкономики. Кроме того, этноэкономическая деятельность способствует гармоничному этническому самовыражению, формированию позитивной этнической идентичности. Не менее важной представляется цель сохранения этнических культур, которая достижима в форме этноэкономического неотрадиционализма, то есть воспроизведения в экономической деятельности этнических традиций и обычаев.

\section{Этноэкономический неотрадиционализм: сферы, формы, практики}

Наша задача видится в выявлении конкретных форм и практик этноэкономического неотрадиционализма и их влияния на региональное экономическое развитие. В рамках этнокультурно-хозяйственной формы неотрадиционализма происходят популяризация и развитие традиционных видов хозяйствования, в том числе на уровне нормативно-правового обеспечения. Выделение территорий традиционного природопользования для представителей коренных малочисленных народов Севера (далее-КМНС) является одной из наиболее ярких практик неотрадиционного хозяйствования. Сюда же мы относим проведение активной маркетинговой политики по продвижению этнической продукции, создание этнически брендированных товаров. Празднично-обрядовая форма неотрадиционализма реализуется через популяризацию традиционных праздников и возрождение обрядности в их проведении. Фольклорная форма находит свое выражение в продвижении этнических коллективов песни и танца, материально-культурная предполагает развитие народно-прикладного искусства, этнической кухни, одежды, а туристско-предпринимательская форма - превращение этнотуризма в бизнес (открытие кафе, баз отдыха и т.д. с «этническим колоритом»). Лингвистическая форма реализуется в сфере выбора основного языка через принцип коммерческой привлекательности и целесообразности использования этнических языков или русского.

Рассмотрение этих конкретных видов неотрадиционализма в регионах Южной Сибири, маркированных экономистами как финансово несамодостаточные (Республика Алтай и Республика
Тыва), позволит выявить общее и особенное в процессах формирования этноэкономических укладов и функционирования этноэкономического неотрадиционализма, а также зафиксировать внимание на формировании «эрзац-культур» как серьезной современной социокультурной проблеме.

\section{Социально-экономическая характеристика регионов}

Республики Алтай и Тыва расположены по соседству на юге Сибирского федерального округа у государственной границы Российской Федерации. Их этническая структура неоднородна: в Республике Алтай 56\% населения составляют русские, 32\%алтайцы и 6\% - казахи. Кроме того, около 4\% жителей региона являются представителями коренных малочисленных народов Севера - теленгиты, тубалары, телеуты, челканцы и кумандинцы. В Тыве преобладающая по численности этническая группа тувинцы (81\% населения), русских там меньше, чем в любом другом сибирском регионе (около 16\%). В горно-таежной части на северо-востоке и юго-востоке республики проживают тувинцы-тоджинцы - субэтническая группа тувинцев, отнесенная к числу $\mathrm{KMHC}^{3}$.

Преобладающей отраслью экономики данных регионов является сельское хозяйство, в основном скотоводство, которое развивается усилиями личных и фермерских хозяйств. Значительная часть продукции производится в личном подсобном хозяйстве.

По объему валового регионального продукта Республика Алтай находится на последнем месте среди регионов РФ (41,8 млрд руб. в 2015 г.). Близок к указанному значению и показатель Тывы - 47,3 млрд руб. за аналогичный период ${ }^{4}$.

Общеэкономические показатели связаны с финансовым благополучием жителей регионов. В обеих республиках в 2016 г.

${ }_{3}^{3}$ Население по национальности и владению русским языком по субъектам РФ (Федеральная служба государственной статистики) (2010) [Эл. pecypc]. URL: http://www. gks.ru/free_doc/new_site/perepis2010/croc/Documents/Vol4/pub-04-04.pdf (дата обращения: 26.03.2018)

${ }^{4}$ Валовый региональный продукт по субъектам Российской Федерации в 1998-2016 гг Федеральная служба государственной статистики. (2016) [Эл ресурc]. URL· http://www. gks.ru/free doc/ne w site/vvp/vrp98-16.xlsx (дата обращения: 22.03.2018). [C. 537] 
в сравнении с 2015 г. среднедушевые месячные доходы населения 5 сократились и составили около 18 тыс. руб. на человека на Алтае и приблизительно 14 тыс. руб. - в Тыве 6 . При этом 66\% населения Алтая и 78\% в Тыве имеют среднедушевой денежный доход за месяц менее 19 тыс. руб. Существенная доля населения республик располагает денежными доходами ниже величины прожиточного минимума: в Республике Алтай в 2016 г. было зафиксировано, что к этой категории относится четверть населения (и доля населения данной категории увеличивается с 2011 г.), в Тыве целых 42\% (рост числа населения данной категории фиксируется статистическими службами с 2012 г.). Для сравнения: в среднем по Российской Федерации доля населения с денежными доходами ниже прожиточного минимума составляет $13 \%$.

Таким образом, и Республику Алтай, и Туву следует относить к бедным регионам с низким уровнем развития экономики.

\section{Этнотуризм: путь к экономическому росту или формированию эрзац-культур?}

Туризм - одна из важнейших отраслей торговли услугами, обеспечивающая в том числе растущую занятость и поступление доходов в региональные и государственный бюджеты. Для регионов, главным источником доходов жителей которых всегда было сельское хозяйство, туристическая привлекательность республик открывает возможности дополнительного заработка.

Горный Алтай, находясь на стыке природных и культурных зон, привлекает большое количество туристов. В настоящее время туризм в республике является одной из основных отраслей экономики, значимым источником дохода жителей. Поскольку регион имеет преимущественно сельскую географию расселения, высока экономическая значимость фактора туризма для жителей сельских районов: «наряду с переработкой сельскохозяйственной продукции, народными промыслами и ремеслами, заготовками дикоросов, строительством, мультисервисом, реальной составляющей агробизнеса становится сельский туризм. Сельский туризм ...оказывает позитивное влияние на сохранение и развитие

${ }_{5}^{5}$ Регионы России. Социально-экономические показатели. 2017. Стат. сб. М.: Росстат, 2017. 1408 c. [C. 237,243$]$.

${ }^{6}$ Там же. С. 243

Там же. С. $280-281$ сельских территорий, рациональное использование их ресурсного потенциала, стимулирует развитие личных подсобных хозяйств, расширяя спрос на экологически чистые, натуральные продукты питания, также обустройство сельских территорий» [Кундиус и др., 2011. С. 113].

К видам туризма, которые способствуют сохранению традиционной культуры жителей региона, не оказывая негативного влияния на окружающую природную среду, традиционно относят экологический и этнографический [Савченко, 2012а. С. 96]. Под этнографическим туризмом в самом общем виде следует понимать знакомство туристов с основами материальной и духовной культуры народа и средой его обитания [Савченко, 20126. С. 95]. Этнотуризм в республике дает возможность «погружения» в природу и историко-культурную среду, он в первую очередь направлен на познание и сохранение историко-культурного наследия коренных (в том числе малочисленных) народов, проживающих в регионе.

С одной стороны, развитие туризма в Республике Алтай способствует росту экономического благосостояния региона. С другой - очевидной становится и серьезность негативных последствий популяризации туризма [Мадюкова, 2016]. Отстраиваются в большом количестве турбазы, для создания маральников и караван-парков огораживаются значительные площади в тайге. Поскольку туристическая инфраструктура в республике не развита должным образом, прием и размещение туристов превращаются в выгодный бизнес для мелких предпринимателей, в общественном сознании легитимизируются практики браконьерства, нарушения законодательства в области защиты окружающей среды и историко-культурного наследия [Ерохина и др., 2015. С. 172].

В Республике Тыва туризм, особенно этнотуризм, развит значительно меньше. К экономическим барьерам развития туризма в регионе относятся следующие факторы: «институты управления туристической индустрией в регионе слабы; дотационность и депрессивность региона; ограниченная транспортная доступность, низкая плотность транспорта, отсутствие железной дороги, значительная удаленность от крупных транспортных, промышленных и социальных центров; отсутствие практики создания благоприятных условий для инвестиций в средства 
размещения туристов и иную туристическую инфраструктуру» [Сунчугашева, 2013. С. 155].

Значимым для нашего исследования является событийный вид этнотуризма в Туве, так как значительное количество туристов из регионов РФ и из-за рубежа посещает именно «этнически маркированные» массовые мероприятия в республике: фестиваль живой музыки и веры Устуу-Хурээ; Дембилдей - конкурс-фестиваль исполнителей горлового пения; национальный новый год Шагаа и др. В то же время исследователи наблюдают на массовых республиканских мероприятиях снижение уровня аутентичности в пользу их зрелищности, процесс «нормализации» (опривычивания) национальной культуры для европейского глаза и уха туристов: «Устуу-Хурээ беззастенчиво миксовал воедино все мыслимые стили, от театрализованного фольклорного профессионального реставраторства до низкокачественного гаражного панка, от классических камерных ансамблей с филармонической пропиской до деревенских исполнителей горлового пения, забывавших переодеться перед выходом на сцену, от инструментального джаз-рока до наивной попсы, где “кровь” и “любовь" рифмуются в каждой песне» [Льноградский, 2012. С. 140].

\section{Природопользование:}

\section{традиционное и современное}

В исследуемых регионах возобновляемые природные ресурсы традиционно потреблялись алтайцами и тувинцами, а также представителями коренных малочисленных народов Севера во время охоты, рыболовства, сбора дикоросов и кочевого скотоводства. Исследователи современного состояния традиционного природопользования, анализируя его аутентичные системы у алтайцев и их адаптационные механизмы, утверждают, что «они представляют собой модели устойчивого развития, функционирующие на основе экологически сбалансированного хозяйства и экофильного общественного сознания» [Дирин, Поливаева, 2013. С. 31]. Нельзя не согласиться с В.В. Поддубиковым, что сохранение традиционной практики природопользования важно не только в экономическом, но и в этнокультурном отношении, «поскольку за рамками исконной хозяйственной специализации зачастую исчезают многие компоненты этнокультуры, включая традиционные знания, материально-, духовно- и нормативно- культурные составляющие и даже значительную часть элементов этнической идентичности. В этих условиях доступ коренного населения к необходимым территориям (которые нередко воспринимаются именно как этнические) критически важен» [Поддубиков, 2012. С. 142].

Справедливым представляется понимание необходимости и в обозримом будущем использования эффективного и малозатратного опыта традиционного природопользования алтайцев для оптимизации современного хозяйственного освоения Алтая и особенно для формирования общественной экологической культуры: «традиционные этнические ценности и представления, уже доказавшие свою состоятельность с точки зрения природоохранных задач, должны стать основой экологического воспитания и образования молодежи» [Дирин, Поливаева, 2013. С. 36].

Современное состояние традиционного природопользования в Республике Алтай представляет собой сложную картину. В ней сочетается как большое количество самого разного рода инициатив и программ социально-экономического развития, исходящих от местных органов власти, бизнеса и других заинтересованных сторон, являющихся причиной большинства поземельных конфликтов, так и в целом ущемление интересов коренного населения, практикующего традиционные формы хозяйствования на территориях строительства предприятий добывающей промышленности, в условиях расширения сети транспортных, энергетических и телекоммуникационных линий, увеличения количества туристических баз. И именно в этом сложном и многоплановом контексте весьма показательным представляется приведенный В.В. Поддубиковым пример злоупотребления традиционным природопользованием с целью получения экономической выгоды в одном из самых популярных уголков Республики Алтай - в районе Телецкого озера. Говоря о запретах на рыболовство на продуктивных участках акватории Телецкого озера, установленных Алтайским государственным биосферным заповедником, он приводит комментарии руководства заповедника, которые указывают на «нетрадиционный» характер природопользования, под которым понимается значительный уровень товарной ориентированности отлавливаемой рыбы: «с развитием в районе Телецкого озера массового туризма и рекреации у местного населения появилась возможность в больших количествах 
сбывать заготовленную рыбу. В результате объемы лова резко увеличились, что стало угрожать истощением запасов наиболее ценных промысловых видов» [Поддубиков, 2012. С. 139].

На современном этапе значительная часть территорий с высоким уровнем биоразнообразия находится в составе особо охраняемых природных территорий, закрытых для массового хозяйственного использования: в Алтае-Саянском экорегионе в настоящее время имеются два национальных парка, девять заповедников, 56 заказников [Система особо охраняемых природных территорий.., 2001]. Однако грань между осуществлением традиционных видов хозяйствования «для себя» и с целью получения экономической выгоды достаточно тонкая, а радикальные решения по сохранению биологического разнообразия действительно могут составлять серьезную преграду как для практик традиционного природопользования, так и для обеспечения туристической привлекательности ${ }^{8}$. Справедливости ради нужно отметить усилия местных властей и частных предпринимателей по привлечению представителей КМНС к обслуживанию туристов и отдыхающих, то есть по развитию альтернативных форм занятости и возможности заработка, не связанных с использованием природных ресурсов, однако такого рода инициативы не всегда и не в полном объеме покрывают экономические потребности местного населения.

\section{Традиционная культура тувинцев и алтайцев и ее экономическая целесообразность}

Трансформация традиционной культуры, выраженная в феномене социокультурного неотрадиционализма, является одной из значимых характеристик современного состояния этнокультур в регионах России. Этнокультуры восстанавливаются или актуализируются на принципиально новых началах, в них появляются рациональность и целесообразность. Разумеется, нельзя не признать, что частичное отмирание некоторых видов художественной деятельности (изготовление седел, уздечек, сундуков, шитье традиционной одежды и обуви) [Кужугет, 2011. С. 138] происходит в связи с тем, что потребность в этих вещных

${ }^{8}$ Прителецкая общественность не согласилась с запретительной концепцией стратегии развития территории (Новости Горного Алтая) (2009) [Эл. ресурc]. URL: http://www. gorno-altaisk.info/news/5651 (дата обращения: 19.03.2018). проявлениях традиционной культуры снижается или отпадает вовсе в связи с модернизацией, сменой образа жизни. С другой стороны, эти объекты материальной культуры в современном мире занимают принципиально иную нишу - нишу индустрии развлечений. Традиционные одежды шьются не для того, чтобы их носить, а для того, чтобы их продавать. Традиционные блюда готовятся не для того, чтобы насытиться, а для того, чтобы получить от них прибыль. Традиционная музыка исполняется не в рамках традиционной или обрядовой деятельности, а для получения популярности и вознаграждения.

Мы не утверждаем, что это - единственная сфера бытования традиционной этнической культуры в современных условиях, однако в рамках данного исследования фокусируем внимание именно на этом ее аспекте. Следует отметить, что манипуляции с традиционными культурами с целью монетизации - не локальное явление. А. К. Кужугет отмечает, что «стремление к накоплению, отказ от традиционных ценностей, общемировая тенденция на расширение индустрии развлечений ведет к уничтожению самой культуры как таковой, замене ее на эрзац-культуру» [Кужугет, 2011. С. 138].

Одним из заметных проявлений такой суррогатной культуры является изготовление «традиционной» одежды и украшений с использованием современных технологий и не аутентичных материалов. Такая ситуация тревожит исследователей традиционной культуры: так, 3.К. Кыргыс отмечает, что массовость изготовления имеет свою отрицательную сторону - низкое качество продукции. В основном мастера копируют ювелирные украшения, в своей работе зачастую используют полуфабрикаты, изготовленные прокаткой, штамповкой [Кыргыс, 2016. С. 152]. При этом «современное потребительское отношение к прикладным изделиям сужает сакральное значение каждого предмета», а «не очень качественные новые “шедевры” продают очень дорого» [Кыргыс, 2016. С. 153]. Выше мы уже говорили о коммерческом злоупотреблении традиционной культурой в сфере оказания туристических услуг и эклектичности сочетания ее элементов с элементами масскульта: например, использование формы юрты в коммерческих проектах туристических баз, с «европейской» отделкой внутри, применение нетрадиционных ингредиентов 
в кухне, удешевление процесса производства традиционного продукта.

Одним из наиболее коммерчески успешных проектов неотрадиционного оформления сельскохозяйственной деятельности с использованием ресурсов традиционного природопользования видится тувинский проект «Одно село - один продукт», реализуемый при поддержке Правительства Республики Тыва. Цель проекта - открытие и развитие производства конкурентоспособной сельскохозяйственной продукции 9 . Значимым для нашего исследования представляется выделение в данном проекте наряду с молоко-, мясо-, рыбоперерабатывающей отраслями, переработкой дикоросов и т.д. туристического кластера и производства национальных продуктов питания, изделий из шерсти и войлока. Промежуточные результаты осуществления проекта публикуются на сайте правительства Республики Тыва. Говорить о ценностноэтической составляющей проекта, наверное, пока рано.

Неотрадиционное развитие национальных видов спорта на территории изучаемых республик осуществляется в рамках масштабных праздничных мероприятий регионального значения. Так, например, в настоящее время на территории Республики Алтай национальные виды спорта включены в спортивную часть ряда республиканских мероприятий. В Туве проводятся соревнования по традиционной борьбе куреш, «стенка на стенку», ритуальный Танец орла по аутентичным правилам. Обратной стороной медали таких соревнований является их эклектичность и включение в одни и те же мероприятия наряду с традиционными видами спорта соревнований по современным, в том числе олимпийским видам спорта. Итоги такого эклектичного смешения А. Кыласов описал на примере эрзац-культуры Кавказских игр: «Анализируя последствия такого “единства”, сразу же обращает на себя внимание эффект контраста технологий современного спорта с “убожеством примитивных забав детей гор”. Посредством такого декларативного противопоставления выявляется превосходство развитого, цивилизованного Центра в отношении “отсталого, дикого” Кавказа» [Кыласов, 2011].

${ }^{9}$ Губернаторский проект «Одно село - один продукт» (Официальный портал Республики Тыва) (2017) [Эл. pecypc]. URL: http://gov.tuva.ru/press_center/news/economy/31684/ (дата обращения: 16.02.2018).
Мы не исключаем, что к подобным выводам могут приходить также зрители мероприятий в республиках Южной Сибири.

Фольклорная форма этноэкономического неотрадиционализма - это создание и продвижение этнических музыкальных коллективов, их гастролирование, а также популяризация горлового пения как особого фольклорного жанра Алтая и особенно Тувы. Специфичность такой формы неотрадиционализма заключается, во-первых, в адаптации аутентичного фольклора («аутентичный фольклор не есть рыночный продукт... Истинный фольклор привязан к образу жизни и ландшафту» [Шапошников, 2017. С. 136]) для европейского слуха посредством профессиональных аранжировок народной музыки, сохраняющих лишь отдельные черты народного исполнения.

Значимо здесь мнение известного музыковеда В. Сузукей, отмечающей, что, с одной стороны, горожанина, и тем более иностранца, привлекает именно необычность тувинской музыки. С другой стороны, утверждает она, «на все, что связано с кочевнической культурой, важно смотреть сквозь призму восприятия жителя юрты. Горожанин, выросший в четырех стенах, воспринимает мир по-другому, он не умеет слышать звуков природы так, как кочевник в своей юрте» [Ламажаа, 2009. С. 144]. Кроме того, современная «национальная» музыка качественно отличается от традиционной уже в период обучения игре на национальных инструментах. Обучение в музыкальных училищах и консерваториях на отделениях национальной музыки происходит на инструментах, адаптированных под оркестровые, на основе нотной грамоты, тогда как традиционное музыкальное «образование» осуществлялось путем наблюдения и подражания. В. Сузукей заключает, что в результате бывают «подготовлены не народные исполнители, а какие-то эрзац... Они настолько отходят от традиционной, чисто тувинской музыки, что народного там близко не остается... И инструменты, на которых их учат, тоже не традиционные, а усовершенствованные» [Ламажаа, 2009. С. 152].

Еще одной характеристикой современной этнической музыки является сформировавшийся в процессе глобализации выбор идеалов для подражания в процессе преемственности среди более коммерчески успешных образцов, а не на выбор мастера, «хотя определенная корреляция между коммерческим 
успехом и мастерством, конечно существует» [Шапошников, 2017. С. 137].

Особо стоит сказать о сложившейся ситуации с этническими языками, хотя она и не является рядоположенной вышеописанным, напротив, примеров «коммерческого» использования этнических языков нам не встретилось. В Республике Алтай в школах алтайский язык не является обязательным предметом, учебники не переиздаются; фактически никто не занимается обновлением алтайского языка с учетом современных, недавно вошедших в лексикон слов. Молодые алтайцы и представители коренных малочисленных народов Севера стремятся изучать русский, а не родной язык, так как русский является более перспективным с точки зрения возможностей получения высшего образования и трудоустройства за пределами региона. Все это приводит к тому, что знание своего языка становится нерациональным и вытесняется в плоскость воспроизводства этнической культуры и этнической идентичности. При этом результаты массовых опросов, проведенных сотрудниками Института философии и права в республике в 2014 г. [Этносоциальные процессы.., 2015], показывают, что от 92 до 98\% респондентов-алтайцев и представителей коренных малочисленных народов Севера заявляют об актуальности и важности для себя знания языка своего народа. Соотнесение значимости владения русским языком с уровнем знания алтайского языка и языков КМНС говорит о том, что высокая рациональная, экономическая целесообразность владения русским оборачивается для алтайцев и представителей КМНС кризисом этнических языков и приводит к невозможности полноценно реализовать свой этнокультурный потенциал.

В Республике Тыва, уникальном российском регионе, где представители тувинского этноса составляют более $80 \%$ населения, языковая ситуация несколько иная: большинство тувинцев являются билингвами. «Тувинско-русское двуязычие можно определить, с одной стороны, как естественное (бытовое), когда тувинцы овладевают русским языком в процессе практической деятельности как языком, необходимым для решения жизненно важных задач, т.к. русский язык выполняет важные общественные функции в жизни тувинцев, а с другой - как субординативное, т.е. доминирующую роль играет родной (тувинский) язык говорящего» [Байкалова, 2015. С. 8]. Автор отмечает, что в республике есть также координативные билингвы (преимущественно выпускники школ Кызыла), которые в равной мере владеют тувинским и русским языком. Тем не менее одной из значимых проблем для современных тувинцев является несовершенство владения русским языком, главные признаки которого - «отсутствие беглости устной речи, низкий уровень сформированности умений в письменной речи на русском языке, однообразие используемых грамматических структур, неправильное фонетическое, лексическое и грамматическое оформление высказываний» [Байкалова, 2015. С. 9].

Таким образом, тувинская билингвальность опосредована двумя основными функциями, которые не могут быть реализованы в одном языке: тувинский используется как комфортный язык бытового общения, определяющий этническую идентичность, а русский - как необходимый инструмент профессиональной успешности и экономической целесообразности.

\section{Заключение}

Таким образом, с одной стороны, социально-экономический прогресс этнических регионов возможен при условии реализации моделей региональной экономики, опирающихся на этноэкономический неотрадиционализм, корни которого лежат в исторически сложившихся типах хозяйствования этнических групп. Такой подход раскрывает потенциал экономического роста для каждой этнической группы и позволяет адаптировать ее традиционные практики хозяйствования к современным экономическим условиям. Реализован такой подход, как показано выше, может быть на уровне как федеральной этнонациональной политики, так и конкретных региональных ведомств и даже отдельных частных предпринимателей. Таким образом, внедрение элементов этноэкономического уклада в систему хозяйствования полиэтничных регионов служит цели сокращения экономической дифференциации регионов при сохранении отличительной специфики этнических культур.

В то же время, признавая существование неотрадиционализма в современной российской реальности как факт, следует указать, что единственно возможным способом существования этнических традиций в современных условиях является их видоизмененное, адаптированное к современным реалиям состояние. 
Однако где проходит та тонкая грань между адаптированной этнической традицией и экземпляром эрзац-культуры, созданным «на потеху» туристам, как нечто экзотичное, противоположное по своей сути глобализационным, масскультным ценностям? Как соблюсти баланс между сохранением исконно традиционного, сакрального и созданием экономически выгодного, массового, но «этнически брендированного» товара? Возможно ли соблюсти этот баланс?

В данной статье мы обозначили формирование этноэкономического уклада с опорой на неотрадиционализм как значимую не только экономическую, но и социокультурную проблему. Сохранение маркеров этничности, реализованных в конкретных, «вещных» объектах этнической культуры, позволяет сохранить этническое многообразие нашей страны, что является значимой стратегической задачей национальной политики. Вместе с тем задача не «скатиться» в сугубо экономическую плоскость путем удешевления производства с одновременным увеличением стоимости конечного продукта «эрзац-культуры», злоупотребления традиционным природопользованием, десакрализации этнической картины мира в целом, не может считаться решенной. Поэтому перспективным направлением как региональных политических и социально-экономических решений, так и академических исследований в рамках данной проблематики, следует считать выявление конкретных механизмов совмещения роста экономического благосостояния дотационных этнических регионов и сохранения их социокультурной специфичности, зафиксированной в конкретных этнических традициях.

\section{Литература}

Байкалова Е.Д. Проблемы обучения двуязычных студентов-тувинцев грамматике английского языка // Языковое образование сегодня - векторы развития. Материалы VI международной научно-практической конференции-форума. Екатеринбург: УГПУ, 2015. С. 7-17.

Бессонов С. А. Традиционализм и модернизация в развивающихся и переходных экономиках. Их влияние на международную конкурентоспособность // Конкурентоспособность и модернизация экономики. Кн. 2. М.: Издательский дом ГУ ВШЭ, 2004. 477 с.

Воронков В.М. Доминирование неписаного права и особенности (пост) советской публичной сферы // Социальная организация и обычное право:
Материалы научной конференции / Отв. ред. А. Н. Мануйлов. Краснодар: РИЦ «Вольные мастера», 2001. С. 227-234.

Гонтарь Н. В. Этноэкономика в контексте регионального развития: структурные особенности и характер влияния на социально-экономические процессы // Управление экономическими системами: Электронный научный журнал. 2015. № 11 (83).

Гудымма А.П. Парадигма ревитализации хозяйственной культуры народов Севера // Проблемы устойчивого развития: иллюзии, реальность, прогноз Материалы VI научного семинара «Самоорганизация устойчивых целостностей в природе и обществе». Томск, 2002. С. 102-110.

Дирин Д.А., Поливаева М.Н. Духовная основа традиционного природопользования коренных этносов Горного Алтая // География и природопользование Сибири. 2013. № 16. С. 30-37.

Дулуш И.Д. Состояние и перспективы организации культурных событийных мероприятий в Туве (на примере Международного фестиваля живой музыки и веры «Устуу-Хурээ») // Новые исследования Тувы. 2012. № 2 (14). С. 29-34.

Ерохина Е.А., Мадюкова С.А., Персидская О.А. Межэтническое сообщество Республики Алтай: этносоциальные и этнокультурные процессы // Философия образования. 2015. № 1 (58). С. 165-177.

Киселева Н.Н., Браткова В.В. Проблемные регионы: сущность и идентификационные признаки // Вектор науки Тольяттинского государственного университетата. 2016. № 4 (30). С. 131-135.

Кужугет А.К. Проблемы преподавания культуры Тувы в образовании XXI века // Сибирский педагогический журнал. 2011. № 11. С. 136-140.

Кундиус В.А., Чермянина В.В., Кудинова М.Г., Балашова С.П., Санталова В.Н. Сельский туризм на Алтае как альтернативный вид деятельности в стратегии диверсификации сельской экономики // Вестник Алтайского государственного аграрного университета. 2011. № 9 (83). С. 113-119.

Кыласов А. Эрзац-культура Кавказских игр (2011) [Эл. pecypc]. URL: https:// dikoe-pole.com/2011/10/12/erzac-kultura/ (дата обращения: 14.02.2018).

Кыргыс 3.К. I Международная научно-практическая конференция по возрождению прикладного искусства, ремесел и верований народов Саяно-Алтайского нагорья (24-27 июля 2016 г., г. Кызыл) // Новые исследования Тувы. 2016. № 3. C. 146-156.

Ламажаа Ч.К. Валентина Сузукей: как бороться с европоцентризмом в центре Азии? // Новые исследования Тувы. 2009. № 1-2. С. 138-154.

Пьноградский Ю. «Устуу-Хурээ»: главное - не бежать впереди зеленой лошади // Новые исследования Тувы. 2012. № 3 (15). С. 135-165.

Мадюкова С.А. Национальная политика и туризм в Республике Алтай // Сибирский философский журнал. 2016. Т. 14. № 4. С. 188-201.

Пика И.А. Неотрадиционализм на российском Севере: идти в будущее, не забывая прошлого // Социологические исследования. 1996. № 11. С. 47-53.

Поддубиков В.В. Коренные малочисленные этносы Алтае-Саянского региона: традиционное природопользование и поземельные отношения в ракурсе проблем межэтнической толерантности // Вестник археологии, антропологии и этнографии. 2012. № 1. С. 136-143. 
Савченко И.М. Традиционное природопользование как основа формирования и функционирования туристско-рекреационного района: на примере Республики Алтай // Проблемы региональной экологии. 2012а. № 4. С. 95-99.

Савченко И.М. Развитие этнографического туризма в Горном Алтае: проблемы и перспективы // Проблемы региональной экологии. 2012б. № 5 . C. $95-98$.

Система особо охраняемых природных территорий Алтае-Саянского экорегиона / Под ред. проф. А.Н. Куприянова. Кемерово: Изд-во «Азия», 2001. 176 с

Сунчугашева Л.А. Проблемы формирования инфраструктуры туризма в приграничном регионе (на примере Республики Тыва) // Инфраструктурные отрасли экономики: проблемы и перспективы развития. 2013. № 3. С. 151-156

Шапошников М.В. Тувинская музыка и World Music // Новые исследования Тувы. 2017. № 2. C. 122-141. DOI: 10.25178/nit.2017.2.5.

Этносоциальные процессы и этнонациональная политика в регионах Сибири / Ю.В. Попков [и др.]; под ред. Ю.В. Попкова. Новосибирск: Изд-во CO PAH, 2015. 273 c.

Статья поступила 05.04.2018.

\section{Summary}

Madyukova S. A., Institute of Philosophy and Law, SB RAS,

Persidskaya O.A., Institute of Philosophy and Law, SB RAS, Novosibirsk

\section{Pthnoeconomics in Action: the Experience of Tuva and Altai}

The potential of the ethnoeconomic structure for the development of models of regional economies, as well as the specific forms and practices of ethnoeconomical non-traditionalism in the life activities of the ethnic groups of the Republics of Tyva and Altai are considered. Specific ethno-cultural traditions and traditional management of Tuvinians and Altaians are considered, on the one hand, as resources of increase of the economic stability of the regions. On the other hand, analysis of the forms of non-traditionalism allowed to record such non-traditional trends as the rationalization and commercialization of the traditional, the tendency to replace the authentic culture with ersatz forms. Specific spheres and mechanisms of monetization of traditional are revealed: ethnotourism and traditional nature management, ethnocuisine and ethno-fashion, throat singing as a brand and low competitiveness of national languages.

Ethnos; ethnoculture; ethnoeconomic structure; ersatz; neotraditionalism

\section{References}

Bajkalova E.D. (2015). Problemy obucheniya dvuyazychnyh studentov-tuvincev grammatike anglijskogo yazyka. In: Yazykovoe obrazovanie segodnya - vektory razvitiya. Materialy VI mezhdunarodnoj nauchno-prakticheskoj konferenciiforuma [Language education today is a vector of development. Materials of the VI International Scientific and Practical Conference-Forum]. Ekaterinburg. USPU Publ. Pp. 7-17. (In Russ.)

Bessonov S.A. (2004) Tradicionalizm i modernizaciya v razvivayushchihsya i perekhodnyh ehkonomikah. Ih vliyanie na mezhdunarodnuyu konkurentosposobnost'. In: Konkurentosposobnost' $i$ modernizaciya ehkonomiki [Competitiveness and modernization of the economy. Vol. 2]. Moscow. State University Higher School of Economics Publ. 477 p. (In Russ.)

Voronkov V.M. (2001). Dominirovanie nepisanogo prava i osobennosti (post) sovetskoj publichnoj sfery. In: Social'naya organizaciya i obychnoe pravo: Materialy nauchnoj konferencii. Krasnodar. Pp. 227-234. (In Russ.)

Gontar' N. V. (2015). Ethnoehkonomika v kontekste regional'nogo razvitiya: strukturnye osobennosti i harakter vliyaniya na social'noehkonomicheskie process. Upravlenie ehkonomicheskimi sistemami: ehlektronnyi nauchnyi zhurnal [Economic Systems Management: an Electronic Scientific Journal]. No. 11 (83). P. 59. (In Russ.)

Gudyma A.P. (2002). Paradigma revitalizacii hozyajstvennoj kul'tury narodov Severa. In: Problemy ustojchivogo razvitiya: illyuzii, real'nost', prognoz. Materialy VI nauchnogo seminara «Samoorganizaciya ustojchivyh celostnostej v prirode $i$ obshchestve» [Problems of sustainable development: illusions, reality forecast: Proceedings of the VI scientific seminar "Self-organization of sustainable integrity in nature and society"']. Tomsk. Pp. 102-110. (In Russ.)

Dirin D.A., Polivaeva M.N. (2013). Duhovnaya osnova tradicionnogo prirodopol'zovaniya korennyh ehtnosov Gornogo Altaya. Geografiya i prirodopol'zovanie Sibiri [Geography and nature management of Siberia]. No. 16. Pp. 30-37. (In Russ.)

Dulush I. D. (2012). Sostoyanie i perspektivy organizacii kul'turnyh sobytijnyh meropriyatij v Tuve (na primere Mezhdunarodnogo festivalya zhivoj muzyki i very "Ustuu-Hureheh»). Novye issledovaniya Tuvy [New research of Tuva]. No. 2 (14) Pp. 29-34. (In Russ.)

Erokhina E.A., Madiukova S.A., Persidskaya O.A. (2015). Mezhetnicheskoe soobschestvo Respubliki Altai: etnosotsialnye i etnokulturnye protsessy. Filosofiya obrazovaniya [Philosophy of Education]. No. 1 (58). Pp. 165-177. (In Russ.)

Kiseleva N.N., Bratkova V.V. (2016). Problemnye regiony: suschnost' i identifikacionnye priznaki Vektor nauki Tol'yattinskogo gosudarstvennogo universitetata [Science Vector of Tolyatti State University]. No. 4 (30). Pp. 131-135. (In Russ.)

Kuzhuget A. K. (2011). Problemy prepodavaniya kul'tury Tuvy v obrazovani XXI veka. Sibirskij pedagogicheskij zhurnal [Siberian pedagogical journal]. No. 11 Pp. 136-140. (In Russ.)

Kundius V.A., Chermyanina V. V., Kudinova M. G., Balashova S.P. Santalova V.N. (2011). Selskii turizm na Altae kak alternativnyi vid deyatelnost v strategii diversifikatsii selskoi ekonomiki. Vestnik Altajskogo gosudarstvennogo agrarnogo universiteta [Vestnik of Altai State Agrarian University]. No. 9 (83). Pp. 113-119. (In Russ.)

Kylasov A. Erzac-kul'tura Kavkazskih igr. (2011). (In Russ.) Available at: https:// dikoe-pole.com/2011/10/12/erzac-kultura/ (accessed 14.02.2018).

Kyrgys Z.K. (2016). I Mezhdunarodnaya nauchno-prakticheskaya konferenciya po vozrozhdeniyu prikladnogo iskusstva, remesel i verovanij narodov SayanoAltajskogo nagor'ya (24-27 iyulya 2016 g., g. Kyzyl). Novye issledovaniya Tuvy [New research of Tuva]. No. 3. Pp. 146-156. (In Russ.)

Lamazhaa Ch. K. (2009). Valentina Suzukej: kak borot'sya s evropocentrizmom v centre Azii? Novye issledovaniya Tuvy [New research of Tuva]. No. 1-2. Pp. 138-154. (In Russ.) 
L'nogradskij Yu. (2012). «Ustuu-Hureheh»: glavnoe - ne bezhat' vperedi zelenoj loshadi. Novye issledovaniya Tuvy [New research of Tuva]. No. 3 (15). Pp. 135-165. (In Russ.)

Madyukova S.A. (2016). Nacional'naya politika i turizm v Respublike Altaj. Sibirskij filosofskij zhurnal [Siberian Philosophical Journal]. Vol. 14. No. 4. Pp. 188-201. (In Russ.)

Pika I.A. (1996). Neotradicionalizm na rossijskom Severe: idti v budushchee, ne zabyvaya proshlogo. Sociologicheskie issledovaniya [Sociological studies]. No. 11. Pp. 47-53. (In Russ.)

Poddubikov V.V. (2012). Korennye malochislennye ehtnosy Altae-Sayanskogo regiona: tradicionnoe prirodopol'zovanie i pozemel'nye otnosheniya $\mathrm{v}$ rakurse problem mezhehtnicheskoj tolerantnosti. Vestnik arheologii, antropologii i ehtnografii [Herald of Archeology, Anthropology and Ethnography]. No. 1. Pp. 136-143. (In Russ.)

Savchenko I. M. (2012a). Traditsionnoe prirodopolzovanie kak osnova formirovaniya i funktsionirovaniya turistsko-rekreatsionnogo rayona: na primere Respubliki Altai. Problemy regionalnoy ekologii [Problems of Regional Ecology]. No. 4. Pp. 95-99. (In Russ.)

Savchenko I. M. (2012b). Razvitie etnograficheskogo turizma v Gornom Altae: problemy i perspektivy. Problemy regionalnoi ekologii [Problems of Regional Ecology]. No. 5. Pp. 95-98. (In Russ.)

Sistema osobo ohranyaemyh prirodnyh territorij Altae-Sayanskogo ehkoregiona (2001). Kemerovo. 176 p. (In Russ.)

Sunchugasheva L.A. (2013). Problemy formirovaniya infrastruktury turizma v prigranichnom regione (na primere Respubliki Tyva). Infrastrukturnye otrasli ehkonomiki: problemy i perspektivy razvitiya [Infrastructure sectors of the economy: problems and development prospects]. No. 3. Pp. 151-156. (In Russ.)

Chaposhnikov M.V. (2017). Tuvan music and World Music. Novye issledovaniya Tuvy [The New Research of Tuva]. No. 2. Pp. 122-141. (In Russ.). doi: 10.25178/ nit.2017.2.5.

Eetnosocial'nye processy i jetnonacional'naja politika v regionah Sibiri. (2015) Novosibirsk. SB RAS Publ, 273 p. (In Russ.) 